\title{
Effects of Nitrogen and Sulfur Fertilizers on Nitrogen Content in Soil, Ear Leaf, Flag Leaf and Grain of QPM Maize Varieties at Samaru Zaria
}

\author{
M. M. Jaliya \\ National Agricultural Extension and Research Liaison Services \\ Ahmadu Bello University Zaria, Nigeria \\ U. F. Chiezey \& B. Tanimu \\ Department of Agronomy, Ahmadu Bello University Zaria, Nigeria
}

A. C. Odunze

Department of Soil Science, Ahmadu Bello University Zaria, Nigeria

M. K. Othman

National Agricultural Extension and Research Liaison Services

Ahmadu Bello University Zaria, Nigeria

B. A. Babaji

Department of Agronomy, Ahmadu Bello University Zaria, Nigeria

B. M. Sani

National Agricultural Extension and Research Liaison Services

Ahmadu Bello University Zaria, Nigeria

H. Mani

Department of Agronomy, Ahmadu Bello University Zaria, Nigeria

Received: August 10, 2011

doi:10.5539/jas.v4n5p217
Accepted: September 6, $2011 \quad$ Online Published: April 1, 2012

URL: http://dx.doi.org/10.5539/jas.v4n5p217

\begin{abstract}
Field trial was conducted in 2006, 2007 and 2008 wet seasons, at the Institute for Agricultural Research Farm, Samaru in the Northern Guinea savanna of Nigeria to determine the effects of nitrogen and sulfur fertilizers on nitrogen uptake of quality protein maize (QPM) varieties. Treatments consisted of four (4) rates each of nitrogen $(0,60,120$ and $180 \mathrm{~kg} \mathrm{~N} / \mathrm{ha})$ and sulfur fertilizer $(0,5,10$ and $15 \mathrm{~kg} \mathrm{~S} / \mathrm{ha})$ and two QPM varieties (Obatampa and EV - 99), laid out in a split plot design with variety and nitrogen in the main plots and sulfur in the sub plots and replicated three times. The results show that varietal differences influenced soil and flag leaf nitrogen in 2006 and 2008 respectively. Nitrogen application did not affect nitrogen content in the soil at all the three years of the trial. However, Ear, Flag and Grain nitrogen content was affected by nitrogen application. Sulfur application influenced soil, ear leaf, flag leaf and grain nitrogen content in different years of the study.
\end{abstract}

Keywords: Quality Protein Maize, Nitrogen, Content, Ear Leaf, Flag Leaf, Soil and Maize Grain 


\section{Introduction}

Maize is one of the most important food crops worldwide and grown between latitude $58^{\circ} \mathrm{N}$ and $49^{0} \mathrm{~S}$ of the equator (Seed Co., 1999). Maize ranks second to wheat in the world cereal production (Kumar, 1993). Maize is the most important cereal in the Sub-Saharan Africa and one of the three most important cereal crops in the world with rice (Oryza sativum L.) and wheat (Triticum aestivum L.) as the other two. Maize is high yielding, easy to process, readily digested and costs less than the other cereals (Kumar, 1993). Varying latitudes have an effect on number of days to flowering and maturity (Seed Co., 1999). This is as a result of higher temperatures at lower altitudes, which accelerate growth while the lower prevailing temperatures at higher altitudes retard growth and extend time to maturity (Seed Co., 1999). Maize is the most important cereal in the United States occupying double the area of all others crops (Kumar, 1993). Some parts of Africa particularly South Africa, Malawi, Zimbabwe, Kenya, Tanzania, Ghana, Nigeria and Egypt are suitable for growing maize and it is fast replacing traditional staple foodstuffs such as Sorghum (Sorghum bicolor L.) and Millet (Pennisetum glaucum L.). Once introduced where the soil and rainfall are suitable for its growth, it quickly replaces the traditional cereals perhaps because of its high yield (Kumar, 1993). It provides nutrients in a compact form, easily transportable and the husk gives protection against birds and rains. It is easy to harvest and harvesting can be spread over a long period (Kumar, 1993).

Maize is used as human food, chemicals, medicines, biofuel, ornamental and other uses e.g. variegated and colored leaf forms as well as those with colorful ears are used Janice et. al., (2010).

Nitrogen is the motor of plant growth and makes up 1 to 4 percent of dry matter of the plants (Anon. 2000). Nitrogen is a component of protein and nucleic acids and when $\mathrm{N}$ is sub-optimal; growth is reduced (Hague et. al. 2001). Nitrogen is the most limiting nutrient in the savanna soils where the soils are predominantly coarse textured and characteristically low in organic matter. Its deficiency is usually recognized first by pale green or yellowish green colour of the leaves, followed by premature necrosis of the older leaves. Where soils are rich in organic matter, such as where the land has just been cleared after a long fallow, a fair amount of nitrogen would be made available to crops through the decomposition of the organic matter (Anon., 1989). Based on the importance of nitrogen as mentioned above, it was chosen as one of the factors of the treatment. Thomas et al. (1984) reported that when $\mathrm{N}$ was sufficient protein content was $55 \%$, but when $\mathrm{N}$ was deficient the value changed to $25 \%$. Protein content did not increase significantly with the addition of $40 \mathrm{~kg} \mathrm{~N}$ ha-', but increased with higher levels of $\mathrm{N}$ to $160 \mathrm{~kg}$ ha' (Gauer, et. al., 1992).

Likewise Sulfur is recognized as the fourth major nutrient after N, P and K. on the average maize crop absorbs as much $\mathrm{S}$ as it absorbs $\mathrm{P}$. When $\mathrm{S}$ is deficient in soil, full yield potential of the crop cannot be realized regardless of other nutrients even under good crop husbandry practices (Tandon, 1989). Deficiency of $\mathrm{S}$ is likely to be widespread in Africa, especially in the savanna regions, where annual bush burning results in losses of sulfur to the atmosphere as Sulfur dioxide $\left(\mathrm{SO}_{2}\right)$ (Tandon, 1989). Ray and Mughogho, (2000) reported that Sulfur is a secondary nutrient that is taken up by most grain crops in amount similar to those of P, namely 10 to $30 \mathrm{~kg} / \mathrm{ha}$. Muhammad et. al. (2004) also reported that S application significantly increased $\mathrm{N}$ uptake by maize plant when sulfur was applied from 0 up to $30 \mathrm{~kg} \mathrm{~S} / \mathrm{ha}$. Significantly higher N uptake was observed when $30 \mathrm{~kg} \mathrm{~S} / \mathrm{ha}$ was applied over $20 \mathrm{~kg} \mathrm{~S} /$ ha but the differences among the rates below $20 \mathrm{~kg} \mathrm{~S} /$ ha were found to be non-significant (Muhammad, et. al., 2004).

Application of sulfur significantly increased the S uptake by maize grain, which may be attributed to increase of $\mathrm{S}$ concentration in plant and dry matter yield. Increasing level of $\mathrm{S}$ progressively enhanced the average total $\mathrm{N}$ uptake by maize. This increase in $\mathrm{N}$ uptake may be attributed to increase in $\mathrm{N}$ content of plant and dry matters yield due to increasing S levels. Such synergistic relationship between N and S has been reported by Sachdev and Deb (1990).

The investigation was therefore, aimed at evaluating the effects of nitrogen and sulfur on $\mathrm{N}$ uptake of quality protein maize (QPM) varieties, yield performance and protein content in grains.

\section{Materials and Methods}

\subsection{Experimental Site}

The experiment was conducted at the Institute for Agriculture Research (IAR) Farm, Samaru, Zaria $\left(11^{0} 11^{\prime} \mathrm{N}\right.$; $07^{0} 38^{\prime} \mathrm{E}$ and 686 meters above sea level), located in the northern Guinea Savanna ecology. The experiment was carried out for three wet seasons, 2006, 2007 and 2008. 


\subsection{Treatment and Experimental Design}

The treatments consisted of two (2) open pollinated quality protein maize (QPM) varieties (Obatampa and EV 99), four rates of nitrogen $(0,60,120$ and $180 \mathrm{kgN} / \mathrm{ha})$ using urea and sulfur $(0,5,10$, and $15 \mathrm{~kg} \mathrm{~S} / \mathrm{ha})$ in the form of potassium sulfate. The experiment was laid out in split plot design with nitrogen and variety in the main plot and sulfur in the subplot. The experiment was replicated three times, each replication comprised of thirty-two plots. Borders between plots within a replication were separated by one meter spacing and between replications by spacing of $1.5 \mathrm{~m}$. Gross plot size was 6 ridges i.e. $4.5 \mathrm{~m}$ by $2.5 \mathrm{~m}$, giving an area of $11.25 \mathrm{~m}^{2}$, while net plot size was 4 ridges i.e. $3.0 \mathrm{~m}$ by $1.5 \mathrm{~m}$ with an area of $4.5 \mathrm{~m}^{2}$.

\subsection{Description of the Varieties Used}

The two varieties of QPM used for this study namely Obatampa and EV-99 were the most popular varieties in the study area, which have reached the hands of the farmers; hence their choice for the study.

\subsection{Cultural Practices}

\subsubsection{Land Preparation, Planting and Fertilizer Application}

The land was double harrowed and then ridged $75 \mathrm{~cm}$ apart. Plots were demarcated after ridging with well-formed borders between plots and replications to minimize nutrient seepage. Sowing was done by hand in June after rainfall to provide moisture for better germination. Two seeds were planted per hole at the spacing of $25 \mathrm{~cm}$ between holes, and then the seedlings were later thinned to one plant per stand at two weeks after sowing. This gave plant population of 53,333 plants per hectare. The nutrients applied were N, P, K and S. However, P and $\mathrm{K}$ were equally applied to all the plots while $\mathrm{N}$ and $\mathrm{S}$ were as the treatment indicated. $\mathrm{N}$ was applied in two equal doses, at 3 and 6 weeks after sowing when the whole of $\mathrm{P}, \mathrm{K}, \mathrm{S}$ and half of $\mathrm{N}$ were applied at three weeks after sowing.

\subsubsection{Pest and Disease Control}

Weeding was done by hoe to control weeds at 3 and 6 weeks after sowing. This was followed by remolding immediately after the second weeding and at the time of second dose of $\mathrm{N}$ fertilizer application. Stem borer infestation was observed, which was controlled by spraying with a combination of cypermethrin and dimethoate at the rate of 1 litre per hectare. No disease was observed throughout the period of the trial.

Ear and flag leaves from the plants in each plot were collected at 50\% tasselling while grains at harvest, oven dried to a constant weight and ground into powder using grinder. The powder was then using 100-mesh sieved and one gram was used for laboratory analysis for $\mathrm{N}$ and $\mathrm{S}$. One gram of the sieved sample was digested using sulfuric acid and perchloric acid with copper and sodium sulfate acting as catalysts. The digest was then used to determine $\mathrm{N}$ and $\mathrm{S}$ content of the leaves. Part of the digest was distilled into boric acid and the distillate was then titrated against a standard hydrochloric acid $(\mathrm{HCl})$ and the percent $\mathrm{N}$ and $\mathrm{S}$ contents were determined from the titre using Macro - Kjedhal method (Bremmer, 1965, IITA 1975). Chemical characteristics of the soils of the trial fields indicated that total nitrogen was low in 2007, medium in 2008 and high in 2006 with values of 0.11, 0.18 and $0.27 \%$ respectively. Varieties did not show any significant grain yield difference in the three years and when averaged over years.

\subsection{Statistical Analysis}

Data collected were subjected to statistical analysis of variance and means of treatments were compared using Duncan Multiple Range Test (DMRT) (Duncan, 1955).

\section{Results}

\subsection{Nitrogen Content in Soil after Harvest}

Effect of varietal differences, nitrogen and sulfur on nitrogen content in soil after harvest is shown in Table 27. Varietal differences had only significant influence on $\mathrm{N}$ content in soil in 2006 whereas Obatampa had significantly higher $\mathrm{N}$ content.

Soil $\mathrm{N}$ content was not influenced by $\mathrm{N}$ application in all the three years. Application of sulfur influenced soil $\mathrm{N}$ content only in 2006. All the three rates produced similar but significantly higher $\mathrm{N}$ in the soil than when sulfur was not applied.

\subsection{Nitrogen Content in Ear Leaf after Harvest}

Effect of varietal differences, nitrogen and sulfur on nitrogen content in ear leaf after harvest is shown in Table 1. Ear leaf $\mathrm{N}$ content was not influenced by varietal differences. Nitrogen significantly influenced ear leaf $\mathrm{N}$ content in 2006 and 2008. Similar and significantly lower ear leaf N content was observed in 2006, when 0 and $60 \mathrm{~kg} \mathrm{~N} / \mathrm{ha}$ 
was applied compared to 120 and $180 \mathrm{~kg} \mathrm{~N} / \mathrm{ha}$ which were statistically similar. In 2008, $120 \mathrm{~kg} \mathrm{~N} / \mathrm{ha}$ produced significantly higher ear leaf $\mathrm{N}$ content than other rates which were statistically similar.

Sulfur fertilizer only influenced ear leaf N content in 2006. Sulfur rate of $5 \mathrm{~kg} /$ ha produced significantly higher N content than the other rates which were statistically similar. Effect of variety, nitrogen and sulfur on nitrogen content in soil, ear leaf, flag leaf and grain after harvest is shown in Table 1. Varieties tested only differ in their flag leaf $\mathrm{N}$ content in 2008 and soil $\mathrm{N}$ content after harvest in 2006 with Obatampa variety giving significantly higher $\mathrm{N}$ content than EV-99.

\subsection{Nitrogen Content in Flag Leaf after Harvest}

Effect of varietal differences, nitrogen and sulfur on nitrogen content in flag leaf after harvest is shown in Table 1. Flag leaf $\mathrm{N}$ content was influenced by varietal differences significantly in 2008 with Obatampa having the highest $\mathrm{N}$ content.

Nitrogen fertilizer applied influenced flag leaf N content in 2007 and 2008. In 2007, $0 \mathrm{~kg} \mathrm{~N} / \mathrm{ha}$ had flag leaves with significantly lower $\mathrm{N}$ content than the other rates which were statistically similar. However, in 2008 flag leaf $\mathrm{N}$ content increased as nitrogen rate increase from 0 up to $120 \mathrm{~kg} \mathrm{~N} / \mathrm{ha}$ but further increase to 180 significantly reduced $\mathrm{N}$ content in the flag leaves.

Flag leaf $\mathrm{N}$ content was only affected by sulfur application in 2007, with $15 \mathrm{~kg}$ S/ha producing significantly higher $\mathrm{N}$ content in the flag leaves than the other $\mathrm{S}$ rates which were statistically similar.

\subsection{Nitrogen Content in Grain after Harvest}

Treatment effect on nitrogen content in grain is shown in Table 1. There was no significant difference in maize grain $\mathrm{N}$ content between the two varieties tested. Nitrogen effect was significant in 2007. Zero N rate produced significantly lower grain $\mathrm{N}$ content compared to the other rates which were statistically similar.

Effect of sulfur was only significantly in 2006 where $5 \mathrm{~kg}$ S/ha produced significantly higher grain $\mathrm{N}$ content than the other $\mathrm{S}$ rates which were statistically similar.

Grain yield/ha and $\mathrm{N}$ uptake by the plant were significantly influenced by nitrogen application in all the three years of the trial. This could be attributed to the fact that yield and yield components depend on better growth and development of the crop which was observed with the plants applied nitrogen fertilizer, hence, better photosynthetic processes for higher assimilate production leading to higher grain yield. A similar trend was also reported by Olowe and Busari, (2000); Okpara et. al., (2007); Mohammed and Fathy, (2009).

\section{Conclusions}

In conclusion the result obtained from this study showed that Obatampa and EV-99 varieties were similar in their $\mathrm{N}$ uptake. The results also showed that, nitrogen content of soil, ear leaf, flag leaf and grain analyzed after harvest was significantly influenced by varietal differences, nitrogen and sulfur fertilizers in some of the three years of the study.

\section{References}

Anonymous. (1989). Fertilizer use and management practices for crops in Nigeria (Series No. 2), (edts): W. O. Enwezor; E. J. Udo; N. J. Usoro; K. A. Ayotade; J. A. Adepeju; V. O. Chude and C. I. Udogbe.

Bremmer, J. M. (1965). Total Nitogen. In C. A. Black ed. Methods of soil analysis part 2: 1149 - 1178. C hemical and Microbiological properties. American Society of Agronomy, Madison, Washington.

Fazli IS, Jamal A, Ahmad S, Masoodi M, Khan JS, Abdin MZ. (2008). Interactive effect of sulphur and nitrogen on nitrogen accumulation and harvest in oilseed crops differing in nitrogen assimilation potential. $J$ Plant Nutri, 31, 1203-1220. http://dx.doi.org/10.1080/01904160802134905

Government of Pakistan. (2003). Economic Survey Govt. of Pakistan, 200 - 2001, Finance Division, Economic and Advisory Wing, Islamabad, Pakistan, pp 15-18.

Gauer, L. E., Grant, C. A., Gehl, D. T., \& Bailey, L. D. (1992). Effects of nitrogen fertilization on grain protein content, nitrogen uptake, and nitrogen use efficiency of six spring wheat (Triticum aestivum L.) cultivars, in relation to estimated moisture supply. Can. J. Plant Sci., 72, 235-241. http://dx.doi.org/10.4141/cjps92-026

Haque, M. M., Hamid, A., \& Bhuiyan, N. I. (2001). Nutirent uptake and productivity as affected by Nitrogen and Potassium application levels in maize/sweet potato intercropping system; Korean Journal of Crop Sciences, 48 (1), $1-5$.

IITA. (1975). Selected methods for soil and plant analysis. IITA Ibadan - Nigeria. 
Jamal A, Moon YS, \& Abdin MZ. (2010). Enzyme activity assessment of peanut (Arachis hypogea) under slow-release sulphur fertilization. Aust J Crop Sci, 4(3), 169-174.

Janice L. Thompson, Melinda M. Manore, \& Linda Ann Vaughan. (2010). Nutrients involved in energy metabolism. The Science of Nutrition (2nd ed.). San Francisco: Pearson Education. pp. 292-321. ISBN 978-0321643162.

Kumar, V. (1993). Crop production in the West Africa Dry lands. In Dry land farming in Africa. J.R.J. Rowland (ed) Mac-Millan press ltd, London, pp $109-141$.

Mahmood, T. (1994). Impact of Water and Nutrient Management on Growth Yield and Quality of Maize (Zea mays L.) PhD Thesis, Department of Agronomy, University of Agriculture, Faisalabad.

Mohammed, A. S., \& Fathy, S. E. (2009). Response of seed yield, seed components and oil content to the sesame cultivar and nitrogen fertilizer rate diversity. Electronic Journal of Environmental, Agricultural and Food Chemistry, 8 (4), 287 - 293.

Muhammad Rasheed, Hakoomat Ali, \& Triq Mahmood. (2004). Impact of Nitrogen and Sulfur application on growth and yield of maize (Zea mays L.) crop.

Okpara D. A., Muoneke C.O., \& Ojikpong T. A. (2007). Effects of nitrogen and phosphorus fertilizer rates on the growth and yield of sesame (Sesamum indicum L.). Indian J. of Agron., 37(4), 258 - 262.

Olowe, V.I.O., \& Busari L.D. (2000). Evolving optimum rates of nitrogen and phosphorus application for sesame in southern guinea savanna of Nigeria. Tropical oil seed Journal. In: Busari L.D. and Olowe V.I.O. (1998). Research on sesame agronomy in Nigeria. First national workshop on beniseed Pp. $75-85$.

Ray R. Weil, \& Spider K. Mughogho. (2000). Sulfur Nutrition of Maize in four regions of Malawi. Crop production department Bunda College of Agriculture, University of Malawi Agronomy Journal, Vol. 92, 649 656.

Seed Co. (1999). Productive Farming. Seed manual Super seed varieties.

Tandon, H.L.S. (1989). Sulfur fertilizer for Indian Agriculture. A Guide Book; Fertilizer Development and Consultation Organization (C-110Greater Kailash-1; New Delhi-110048, India pp 1-4.

Thomas WH, Seibert DLR, Alden M, Neori A, \& Eldridge P. (1984). Yields, photosynthetic efficiencies and proximate composition of dense marine microalgal cultures. I. Introduction and Phaeodactylum tricornutum experiments, 5(3), 181-209. 
Table 1. Effects of Nitrogen and Sulfur Fertilizers on N Content of Soil, Ear Leaf, Flag Leaf and Grain of QPM Maize Varieties after Harvest

\begin{tabular}{|c|c|c|c|c|c|c|c|c|c|c|c|c|}
\hline \multirow[b]{2}{*}{ Treatment } & \multirow{2}{*}{$\begin{array}{l}\text { Soil N } \\
\text { Harvest } \\
2006 \\
\end{array}$} & \multirow{2}{*}{$\begin{array}{l}\text { Content } \\
2007 \\
\end{array}$} & \multirow{2}{*}{$\begin{array}{l}\text { After } \\
2008 \\
\end{array}$} & \multicolumn{3}{|c|}{$\begin{array}{l}\text { Ear Leaf N Content After } \\
\text { Harvest }\end{array}$} & \multicolumn{3}{|c|}{$\begin{array}{l}\text { Flag Leaf N Content After } \\
\text { Harvest }\end{array}$} & \multicolumn{3}{|c|}{$\begin{array}{l}\text { Maize Grain N Content After } \\
\text { Harvest }\end{array}$} \\
\hline & & & & 2006 & 2007 & 2008 & 2006 & 2007 & 2008 & 2006 & 2007 & 2008 \\
\hline \multicolumn{13}{|l|}{ QPM Variety } \\
\hline Obatampa & & 0.80 & & & & & & & & 12.43 & & \\
\hline V1 & $0.51 \mathrm{a}$ & & 1.03 & 16.39 & 21.42 & 16.76 & 18.79 & 23.85 & $21.39 \mathrm{a}$ & & 13.21 & 13.93 \\
\hline EV-99 V2 & $0.42 b$ & 0.81 & 0.92 & 16.31 & 22.70 & 18.11 & 18.33 & 23.42 & $20.07 b$ & 12.09 & 13.38 & 14.10 \\
\hline S.E. \pm & 0.017 & 0.023 & 0.055 & 0.223 & 0.519 & 0.475 & 0.284 & 0.205 & 0.309 & 0.124 & 0.104 & 0.092 \\
\hline Significance & $* *$ & NS & NS & NS & NS & NS & NS & NS & $* *$ & NS & NS & NS \\
\hline \multicolumn{13}{|l|}{ Nitrogen } \\
\hline \multicolumn{13}{|l|}{ Fertilizer } \\
\hline \multicolumn{13}{|l|}{ (kg/ha) } \\
\hline 0 & 0.50 & 0.80 & 0.82 & $16.30 \mathrm{ab}$ & 23.59 & $17.51 \mathrm{~b}$ & 18.49 & $23.1938 \mathrm{a}$ & $18.7125 \mathrm{c}$ & 11.9188 & $12.8806 \mathrm{~b}$ & 14.2506 \\
\hline 60 & 0.49 & 0.79 & 0.94 & $15.49 \mathrm{~b}$ & 21.65 & $16.13 b$ & 18.04 & $25.5000 \mathrm{~b}$ & $20.9425 b$ & 12.2375 & $13.5006 \mathrm{a}$ & 13.9469 \\
\hline 120 & 0.44 & 0.81 & 1.11 & $17.13 \mathrm{a}$ & 21.33 & $19.93 \mathrm{a}$ & 18.57 & $23.1438 b$ & $22.3694 a$ & 12.6688 & 13.3331a & 13.7194 \\
\hline 180 & 0.43 & 0.80 & 1.02 & $16.48 \mathrm{a}$ & 21.67 & $16.16 \mathrm{~b}$ & 19.13 & $22.7063 b$ & $20.9013 b$ & 12.2250 & $13.4563 \mathrm{a}$ & 14.1413 \\
\hline S.E. \pm & 0.0242 & 0.0322 & 0.0772 & 0.3147 & 0.7338 & 0.6717 & 0.401 & 0.29 & 0.4372 & 0.1759 & 0.1467 & 0.1292 \\
\hline Significance & NS & NS & NS & $*$ & NS & $* *$ & NS & $* *$ & $* *$ & NS & $*$ & NS \\
\hline \multicolumn{13}{|l|}{ Sulfur } \\
\hline \multicolumn{13}{|l|}{ Fertilizer (kg } \\
\hline \multicolumn{13}{|l|}{ S/ha) } \\
\hline 0 & $0.43 b$ & 0.78 & 0.93 & $15.61 \mathrm{~b}$ & 21.12 & 18.26 & 18.82 & $23.26 \mathrm{~b}$ & 21.18 & $11.98 \mathrm{~b}$ & 13.33 & 14.25 \\
\hline 5 & $0.47 \mathrm{a}$ & 0.82 & 0.92 & $17.4 \mathrm{a}$ & 22.51 & 17.53 & 18.68 & $22.65 b$ & 19.76 & $12.79 \mathrm{a}$ & 13.45 & 13.92 \\
\hline 10 & $0.46 a b$ & 0.81 & 1.09 & $15.97 \mathrm{~b}$ & 22.63 & 16.56 & 18.54 & $22.9 \mathrm{~b}$ & 21.32 & $12.08 \mathrm{~b}$ & 13.03 & 13.54 \\
\hline 15 & $0.50 \mathrm{a}$ & 0.80 & 0.95 & $16.36 \mathrm{~b}$ & 21.99 & 17.37 & 18.20 & $25.71 \mathrm{a}$ & 20.67 & $12.21 \mathrm{~b}$ & 13.36 & 14.35 \\
\hline S.E. \pm & 0.013 & 0.022 & 0.055 & 0.284 & 0.515 & 0.428 & 0.419 & 0.491 & 0.509 & 0.180 & 0.236 & 0.316 \\
\hline Significance & $* *$ & NS & NS & $* *$ & NS & NS & NS & $* *$ & NS & $*$ & NS & NS \\
\hline
\end{tabular}

Means followed by the same letter(s) within a treatment group are not significantly different at 5 percent level of significance using DMRT

NS $=$ Not Significant

$*=$ Significant at $5 \%$ level of Significance

$* *=$ Significant at $1 \%$ level of Significance 